\title{
Seasonal Incidence of Mustard Aphid Lipaphis erysimi (Kalt.) and its Correlation with Weather Factors under Terai Zone of West Bengal
}

\author{
B. K. Sreedhar ${ }^{*}$, T. K. Hath ${ }^{2}$, S. K. Sahoo ${ }^{2}$ and Supriya Okram ${ }^{2}$ \\ ${ }^{1}$ Department of Entomology, Anand Agricultural University, Anand, Gujarat, India \\ ${ }^{2}$ Department of Entomology, Uttar Banga Krishi Viswavidyalaya, Pundibari, Cooch Behar, \\ West Bengal, India \\ *Corresponding author
}

\begin{tabular}{|l|}
\hline K e y w o r d s \\
$\begin{array}{l}\text { Mustard aphid, } \\
\text { Lipaphis erysimi, } \\
\text { Indian mustard, } \\
\text { Brassica juncea, } \\
\text { and Abiotic factors }\end{array}$ \\
\hline Article Info \\
\hline $\begin{array}{l}\text { Accepted: } \\
\text { 15 December } 2020 \\
\text { Available Online: } \\
\text { 10 January } 2021\end{array}$ \\
\hline
\end{tabular}

\section{A B S T R A C T}

Mustard crop is susceptible to many number of insect pests particularly mustard aphid (Lipaphis erysimi) a key pest which causes significant damage to the crop. To examine the incidence of aphid to different abiotic factors on Indian mustard (Brassica junceacv.Rohini) a field experiment was carried out at Institutional farm, Uttar Banga Krishi Viswavidyalaya, Pundibari, Cooch Behar, West Bengal for two successive Rabi seasons during 2016-17 and 2017-18. The prevalence of aphid population was first seen during the month of January ( $3^{\text {rd }}$ Standard Meteorological Week) with 0.75 aphids/ top 10 $\mathrm{cm}$ apical shoot and it persisted in the field up to March $\left(11^{\text {th }}\right.$ Standard Meteorological Week) with 52.12 aphids/ top $10 \mathrm{~cm}$ apical shoot. Maximum population of 85.33 aphids/top $10 \mathrm{~cm}$ apical shoot was recorded during February $\left(8^{\text {th }}\right.$ Standard Meteorological Week) in 2016-17. Further, in 2017-18 the frequency of aphid was first noticed in the month of February ( $4^{\text {th }}$ Standard Meteorological Week) with 5.0 aphids/top $10 \mathrm{~cm}$ apical shoot and sustained in the field up to March ( $11^{\text {th }}$ Standard Meteorological Week) with 2.14 aphids/top $10 \mathrm{~cm}$ apical central shoot. Peak population was observed during February $\left(6^{\text {th }}\right.$ Standard Meteorological Week) with 50.33 aphids/top $10 \mathrm{~cm}$ apical shoot. Subsequently, correlation studies also made between aphid population and weather factors. Aphid was positively correlated with maximum and minimum temperature and negatively correlated with maximum relative humidity and positively correlated with minimum relative humidity and with rainfall it shows positive correlation. Aphid showed significant correlation with minimum temperature and maximum relative humidity during 2016-17. In 2017-18 aphid is negatively correlated with both maximum and minimum temperature, while positively correlated with both maximum and minimum relative humidity. Aphid is negatively correlated with rainfall.

\section{Introduction}

Oil seed crops are gaining a momentum in cultivation after cereals and pulses. Among the oilseed crops rapeseed-mustard occupies a prominent place both in cultivation and production. In India it grows predominantly in Rajasthan, Uttar Pradesh, Madhya Pradesh, West Bengal, Haryana, Punjab and Assam (Shekhawat et al., 2012). Among different 
rapeseed-mustard groups, Indian mustard (Brassica juncea L.) is predominantly grown in different parts of the country. It is widely known as 'Mohari', 'Rai' or'Raya' in various parts of the country. In India, Mustard is grown in the area of $6.3 \mathrm{M}$ ha with production of 7.6 M tonnes and productivity of 11.90 q/ha (Ali et al., 2010).Despite large scale cultivation of mustard, it is vulnerable to numerous insect pests. Mustard aphid alone causes significant loss which accounts for 65 to $96 \%$ of losses in seed yield (Bakhetia, 1984) and $15 \%$ loss in oil content (Verma and Singh, 1981).According to (Bakhetia and Sekhon, 1989) a total of 38 insect pests alone contribute to rapeseed- mustard crop. Purwar et al.(2004) categorized more than 43 species of insect pests infesting rapeseed- mustard crop.Among the insect pests infesting mustard crop, mustard aphid (Lipaphis erysimi Kalt.) (Aphididae: Hemiptera) is one of the major devastating insect pest in India (Bakhetia, 1991; Arora, 1999; Rai 1976 and Rohilla et al., 1987). Damage symptoms attribute both the nymphs and adults suck the sap from different parts of the plant viz., vegetative, flowering and pod formation stages and thereby it causes severe injury to the plant. As a result, plant resembles non vigorous and the growth becomes stunted (Husain and Begum, 2009). Under North Indian climatic conditions, aphids remain active from November to March with maximum population during mid-February to midMarch.

Abiotic factors play a crucial role in rapid multiplication of aphids (Sinha et al., 1989; Rana et al., 1993; Singh and Malik, 1998). Therefore, a study was undertaken to determine the incidence and fluctuation of mustard aphid against different abiotic factors during the crop period in order to follow essential management tactics from the threat posed by mustard aphid in cultivation of mustard crop.

\section{Materials and Methods}

In order to achieve the objective, field experiment was conducted at Instructional Farm, Uttar Banga Krishi Viswavidyalaya, Pundibari, Cooch Behar, West Bengal to study the population build up of mustard aphid against weather factors. Indian mustard (Brassica junceacv. Rohini)is selected to ascertain the seasonal incidence of aphid during two successive Rabi seasons 2016-17 and 2017-18, respectively. The statistical design followed during the experimental period was Randomized Block Design (RBD).Seeds of Indian mustard were procured from Pulse and Oilseed Research Station, Berhampur, West Bengal.Seeds were sown in $10 \times 10 \mathrm{~m}$ plot with a spacing of $30 \mathrm{~cm} \times 10 \mathrm{~cm}$ between row to row and plant to plant. Recommended dose of fertilizer @ 80:40:40 (N: P: Kkg/ha) is followed during the crop period except, no plant protection measures are taken throughout the crop period.

\section{Aphid observation}

An observation on the population of mustard aphid was recorded by counting the number of aphids visually from top $10 \mathrm{~cm}$ apical central shoot at weekly intervals. For this, five plants were selected randomly tagged and average aphid populations per plant were thus calculated. Besides, data on weather parameters like maximum and minimum temperature, maximum and minimum relative humidity and rainfall were collected and correlated with aphid population.

\section{Results and Discussion}

Incidence of mustard aphid during 2016-17

Data recorded at weekly intervals in the year 2016-17 are presented in table no 1.It reveals that the aphid population was first appeared 
during the month of January $3{ }^{\text {rd }}$ Standard Meteorological Week with 0.75 aphid/top 10 $\mathrm{cm}$ apical shoot and it remained present in the field up to $11^{\text {th }}$ Standard Meteorological Week (March). During the month of February $8^{\text {th }}$ Standard Meteorological Week when profuse flowering started, maximum population of (85.33 aphids)/top $10 \mathrm{~cm}$ apical shoot was observed. It is observed from the table that the aphid population gradually increased from its first appearance on $\quad 3{ }^{\text {rd }}$ Standard Meteorological Week and reached its peak on $8^{\text {th }}$ Standard Meteorological Week and thereafter the population started declining although on the last date of observation i.e., on $11^{\mathrm{th}}$ Standard Meteorological Week, there was 52.12 aphids/top $10 \mathrm{~cm}$ apical shoot which signifies that population density was much higher.

Table.1 Weekly Incidence of mustard aphid in relation with weather parameters on Brassica juncea cv. Rohini during Rabi 2016-17

\begin{tabular}{|c|c|c|c|c|c|c|}
\hline \multirow[t]{2}{*}{ SMW } & \multirow{2}{*}{$\begin{array}{l}\text { Mean aphid population } \\
\text { (top } 10 \mathrm{~cm} \text { apical } \\
\text { shoot) / } 5 \text { plants }\end{array}$} & \multicolumn{2}{|c|}{$\begin{array}{c}\text { Temperature } \\
\left({ }^{\circ} \mathrm{C}\right)\end{array}$} & \multicolumn{2}{|c|}{$\begin{array}{c}\text { Relative Humidity } \\
(\%)\end{array}$} & \multirow[t]{2}{*}{$\begin{array}{l}\text { Rainfall } \\
\text { (mm) }\end{array}$} \\
\hline & & Max. & Min. & Max. & Min. & \\
\hline $3^{\text {rd }}$ & 0.75 & 25.72 & 8.06 & 97.14 & 44.71 & 0.00 \\
\hline $4^{\text {th }}$ & 2.73 & 28.10 & 10.54 & 97.14 & 42.71 & 0.00 \\
\hline $5^{\text {th }}$ & 5.80 & 25.17 & 11.31 & 97.86 & 58.43 & 0.00 \\
\hline $6^{\text {th }}$ & 5.00 & 28.11 & 11.16 & 97.86 & 44.43 & 0.00 \\
\hline $7^{\text {th }}$ & 35.00 & 28.67 & 11.36 & 97.57 & 46.71 & 0.00 \\
\hline $8^{\text {th }}$ & 85.33 & 28.49 & 13.30 & 97.29 & 56.00 & 0.00 \\
\hline $9^{\text {th }}$ & 82.26 & 28.59 & 14.27 & 94.43 & 45.00 & 0.00 \\
\hline $10^{\text {th }}$ & 78.23 & 29.54 & 14.23 & 92.43 & 49.29 & 5.34 \\
\hline $11^{\text {th }}$ & 52.12 & 26.73 & 13.07 & 95.57 & 50.57 & 1.37 \\
\hline
\end{tabular}

SMW= Standard Meteorological Week Max= Maximum Min= Minimum mm= Millimetre

Table.2 Weekly Incidence of mustard aphid in relation with weather parameters on Brassica juncea cv. Rohini during Rabi 2017-18

\begin{tabular}{|c|c|c|c|c|c|c|}
\hline \multirow[t]{2}{*}{ SMW } & \multirow{2}{*}{$\begin{array}{l}\text { Mean aphid population } \\
\text { (top } 10 \mathrm{~cm} \text { apical shoot) } \\
\text { / } 5 \text { plants }\end{array}$} & \multicolumn{2}{|c|}{$\begin{array}{l}\text { Temperature } \\
\left({ }^{0} \mathrm{C}\right)\end{array}$} & \multicolumn{2}{|c|}{$\begin{array}{c}\text { Relative Humidity } \\
(\%)\end{array}$} & \multirow[t]{2}{*}{$\begin{array}{c}\text { Rainfall } \\
\text { (mm) }\end{array}$} \\
\hline & & Max. & Min. & Max. & Min. & \\
\hline $4^{\text {th }}$ & 5.00 & 23.13 & 9.84 & 98.71 & 60.14 & 0.00 \\
\hline $5^{\text {th }}$ & 15.67 & 22.96 & 10.07 & 96.00 & 57.00 & 0.00 \\
\hline $6^{\text {th }}$ & 50.33 & 23.96 & 9.66 & 91.14 & 57.43 & 0.00 \\
\hline $7^{\text {th }}$ & 50.21 & 24.83 & 11.31 & 88.86 & 56.14 & 0.00 \\
\hline $8^{\text {th }}$ & 18.21 & 27.07 & 12.07 & 82.14 & 48.29 & 0.00 \\
\hline $9^{\text {th }}$ & 12.04 & 28.04 & 14.00 & 75.14 & 45.14 & 0.00 \\
\hline $10^{\text {th }}$ & 8.12 & 27.73 & 16.34 & 81.86 & 60.71 & 0.91 \\
\hline $11^{\text {th }}$ & 2.14 & 30.23 & 15.59 & 65.00 & 44.71 & 0.00 \\
\hline
\end{tabular}

$\mathrm{SMW}=$ Standard Meteorological Week Max = Maximum Min = Minimum mm=Millimetre 
Table.3 Correlation co-efficient (r) of mustard aphid with different weather factors during 201617 and 2017-18

\begin{tabular}{|c|c|c|c|c|c|}
\hline \multirow{2}{*}{ Years } & \multicolumn{2}{|c|}{ Temperature $\left({ }^{\mathbf{0}} \mathbf{C}\right)$} & \multicolumn{2}{c|}{ Relative humidity (\%) } & \multirow{2}{*}{ Rainfall (mm) } \\
\cline { 2 - 5 } & Max. & Min. & Max. & Min. & \\
\hline $\mathbf{2 0 1 6 - 1 7}$ & 0.605 & $\mathbf{0 . 8 7 9}$ & $\mathbf{- 0 . 6 7 3}^{* *}$ & 0.265 & 0.440 \\
\hline $\mathbf{2 0 1 7 - 1 8}$ & -0.435 & -0.513 & 0.349 & 0.259 & -0.253 \\
\hline$* * *$ Correlation is significant at the 5\% level and $1 \%$ level, respectively
\end{tabular}

*,** Correlation is significant at the $5 \%$ level and $1 \%$ level, respectively

Incidence of mustard aphid during 2017-18

In 2017-18, data recorded at weekly intervals are furnished in table no 2. It is evident from the results that aphid population was first observed during (February) $4^{\text {th }}$ Standard Meteorological Week with 5 aphids/top $10 \mathrm{~cm}$ apical shoot and peak population was observed at $6^{\text {th }}$ standard meteorological week (February) with 50.33 aphids /top $10 \mathrm{~cm}$ apical shoot. There was a sharp increase in aphid population from $4{ }^{\text {th }}$ Standard Meteorological Week (SMW) to $6{ }^{\text {th }}$ Standard Meteorological Week (SMW). Thereafter aphid population decrease gradually and the lowest population was recorded on $11^{\text {th }}$ Standard Meteorological Week (SMW) (March) with (2.14 aphids/top $10 \mathrm{~cm}$ apical shoot). Results reveal that aphids remained present in the field for seven weeks.

From two years data it is observed that aphid occurred during $\quad 3^{\text {rd }}$ to $\quad 4^{\text {th }}$ Standard Meteorological Week (SMW) and remained active for a period of 7-8 weeks and their population remained high in both the years.

\section{Correlation of mustard aphid with weather factors during 2016-17 and 2017-18}

Incidence of mustard aphid was correlated with abiotic factors. In the year 2016-17 Aphid was positively correlated with maximum temperature $(\mathrm{r}=0.06)$ and shows significant positive correlation with minimum temperature $\left(\mathrm{r}=0.879^{* *}\right)$ while, aphid exhibits significant negative correlation with maximum relative humidity $(\mathrm{r}=-0.673 *)$ and positively correlated with minimum relative humidity $(r=0.265)$. Besides, Aphid showed positive correlation $(\mathrm{r}=0.440)$ with rainfall. In the year 2017-18 aphid is negatively correlated with both maximum $(r=-0.435)$ and minimum temperature $\quad(\mathrm{r}=\quad-0.513)$ respectively. Aphid shows positive correlation with both maximum relative humidity ( $\mathrm{r}=$ 0.349 ) and minimum relative humidity ( $\mathrm{r}=$ $0.259)$. Aphid is negatively correlated $(r=-$ 0.253 ) with rainfall. Data on correlation coefficient (r) with weather factors against mustard aphid are presented in table no.3.

The above results are supported by Ahuja (1990) found that aphid appeared in late December which reached its peak between $4^{\text {th }}$ week of January to $1^{\text {st }}$ week of February. Sahoo (2012) recorded the appearance of aphid from $52^{\text {nd }}$ SMW with the peak population during $6{ }^{\text {th }} \mathrm{SMW}$. Kumar et al., (1999), who reported that the mustard aphid appeared on the Brassica species on $3{ }^{\text {rd }}$ SMW and reached at peak in the $6^{\text {th }}$ to $7^{\text {th }}$ SMW and thereafter it declined after the $9{ }^{\text {th }}$ SMW, which is almost in line with the present findings. Thakur (1976) observed that the temperature above $28.8^{\circ} \mathrm{C}$ and relative humidity below $62.2 \%$ adversely affect the population of aphids. Gour and Pareek (2003) observed a negative correlation between maximum $\left(24.83-28.49^{\circ} \mathrm{C}\right)$ and minimum temperature $\left(11.31-13.3^{\circ} \mathrm{C}\right)$ and relative humidity and aphid population build up is in accordance with the present findings. 
From the above findings, it can be concluded that mustard aphid population appeared in both the years 2016-17 and 2017-18 with higher population at $8^{\text {th }}$ Standard Meteorological Week during 2016-17 and $6^{\text {th }}$ Standard Meteorological Week during 201718. Abiotic factors had influenced the aphid population in both the years. Maximum temperature and relative humidity had shown significant impact on aphid population fluctuation in 2016-17. Therefore, adjusting the date of sowing is pre-requisite in management of mustard aphid.

\section{Acknowledgement}

Authors are greatly thankful to Department of Entomology, Uttar Banga Krishi Viswavidyalaya for their unconditional support with good expertise, which helped to complete the research work smoothly.

\section{References}

Ahuja, D.B. 1990. Population dynamics of mustard aphid Lipaphis erysimi(Kalt.) on Indian mustard, Brassica juncea(subsp. juncea).Indian Journal of Plant Protection, 18(8): 233-235.

Ali, A., Rizvi, P.Q. and Khan,F.R. 2010. Bioefficacy of some plant leaf extracts against mustard aphid, Lipaphis erysimi Kalt. on Indian mustard, Brassica juncea. Journalof Plant Protection Research.,50 (2): 130-132.

Arora, R.1999. Major insect pests of rapeseed-mustard and their management.InIPM System inAgriculture Oilseeds.Vol. V.Upadhyay, R.K, Mukharji, K.G, Rajak, R.L.(Eds) Aditya Books Pvt. Ltd., New Delhi. pp. 35-75.

Bakhetia, D.R.C andSekhon, B.S. 1989. Insect pests and their management in rapeseed- cabbage and their natural enemies. Indian Journal of Entomology,
74: 236-240.

Bakhetia, D.R.C. 1984. Chemical control of Lipaphis erysimi (Kaltenbach) on rapeseed and mustard crop in Punjab.Journal of Research Punjab Agricultural University.21: 63-75.

Bakhetia, D.R.C.1991The insects: In Oilseed Brassicas in Indian Agriculture.(eds) Chopra V. L., Sham Prakash. HarAnand Publications, 1991.

Gour, I.S. and Pareek, B.L. 2003.Seasonal incidence of major insect-pests of mustard crop and their correlation with abiotic factors under semiarid region of Rajasthan. Journal of insect science, 16: 37-40.

Husain, M and Begum, M.A. 2009. Number of insect pests attack mustard. Journal of Agriculture Research. Vol. 46.

Kumar, J., Mallik, Y.P and Singh, S.V. 1999. Forecasting models for outbreak of Lipaphis erysimion some cultivars of mustard, Brassica juncea. Indian Journal of Entomology, 61(1): 59-64.

Purwar, J.P., Singh, R.K and Mall, P.2004.Eco-friendly management of insect pests in rapeseed- mustard.Indian Farmers Digest,37: 34-35.

Rai, B.K. 1976.Pests of oilseed crops in India and their control.Indian Council of Agricultural Research, New Delhi.pp. 100-121.

Rana, J.S.,Khokar, K.S., Singh, $H$ and Sucheta, 1993. Influence of abiotic environment on the population dynamics of mustard aphid. Lipaphis erysimi (Kalt.).Crop Research, 6: 116119.

Rohilla, H.R., Singh, H, Kelra, V.K and Kharub, S.S.1987.Losses caused by mustard aphid, L. erysimi(Kalt.) in differentBrassica genotype. Proc. $7^{\text {th }}$ International Rapeseed Congress,5: $1077-1083$.

Sahoo, S.K.2012.Incidence and management of mustard aphid (Lipaphis 
erysimiKaltenbach) in West Bengal. The Journal of Plant Protection Sciences,4(1):20-26.

Singh, S.V. and Y.P. Malik, 1998. Population dynamics and economic threshold of Lipaphis erysimi (Kaltenbach) on mustard.Indian Journal of Entomology, 60: 43-49.

Sinha, R.P., S.S. Yazdani and G.D. Verma, 1989. Population dynamics of mustard aphid, Lipaphis erysimi (Kalt.) in relation to ecological parameters. Indian Journal of Entomology, 51: 334-339.

Thakur, D.K. 1976. Pest complex of mustard crop and relative efficacy of some important insecticides against important insect-pests of mustard crop.Thesis Abstract (H.A.U.), 2(2): 119.

Verma, S.N and Singh, O.P.1987.Estimation of avoidable losses to mustard by the aphid, Lipaphis erysimiin Madhya Pradesh.Indian Journal of Plant Protection, 15: 87-89.

Shekhawat, K., Rathore,S. S., Premi, O. P., Kandpal,B. K. and Chauhan, J. S. 2012.Advances in Agronomic Management of Indian Mustard (Brassica juncea (L.)Czernj.Cosson): An Overview. International Journal of Agronomy.pp. 1-14.

\section{How to cite this article:}

Sreedhar, BK., TK. Hath, SK. Sahoo and Supriya Okram. 2021. Seasonal Incidence of Mustard Aphid Lipaphis erysimi (Kalt.) and its Correlation with Weather Factors under Terai Zone of West Bengal. Int.J.Curr.Microbiol.App.Sci. 10(01): 2555-2561. doi: https://doi.org/10.20546/ijcmas.2021.1001.296 